Research Article

\title{
Study to assess knowledge, attitude and practice regarding swine flu vaccine amongst medical students
}

\author{
Rajvardhan R. Solunke*, Shrikant C. Dharmadhikari, Jugalkishore B. Jaju, Ganesh R. Pawar, \\ Aruna Gurung
}

Department of Pharmacology, Government Medical College, Latur, Maharashtra, India

Received: 29 June 2016

Accepted: 05 August 2016

*Correspondence to:

Dr. Rajvardhan R. Solunke,

Email: drrajsolunke07@gmail.com

Copyright: (c) the author(s), publisher and licensee Medip Academy. This is an open-access article distributed under the terms of the Creative Commons Attribution Non-Commercial License, which permits unrestricted non-commercial use, distribution, and reproduction in any medium, provided the original work is properly cited.

\begin{abstract}
Background: Due to recurrent outbreak and associated high mortality of swine flu there is panic amongst medical students also because of higher risk of getting infected. Vaccination for swine flu is the best preventive measure. So this study was undertaken. The aim of the present study was to assess the knowledge, attitude and practice regarding swine flu vaccine amongst medical students of government medical college and provide data to improve awareness about swine flu vaccine

Methods: This was a cross sectional observational study carried out amongst 250 medical students during period of April-June 2015. A pre designed and pre tested, multiple choice questionnaires was used to assess KAP regarding swine flu vaccine and descriptive analysis was done.

Results: Knowledge of participants regarding Swine flu vaccine was high as the mean score of correct answers marked was 152.5. But Only $21.8 \%$ participants had knowledge about cost of vaccine and $33.2 \%$ about the adverse drug reactions to the vaccine. Internet was the most common source of information amongst participants. Attitude of participants toward vaccination was favourable (mean score -128.4) but attitude for vaccination during pregnancy $(30.8 \%)$ and with other vaccines $(32.8 \%)$ was unfavourable. Only $30(12 \%)$ candidates have taken the vaccine which shows very poor practice.

Conclusions: This study shows high knowledge, favourable attitude but poor practice towards Swine flu vaccination amongst medical students. So there is need to increase awareness for vaccination of swine flu amongst medical students by continuous health education and also need to increase the availability of vaccine in government hospitals.
\end{abstract}

Keywords: Swine flu vaccine, Medical students, Knowledge, Attitude, Practice

\section{INTRODUCTION}

Swine influenza, a highly contagious respiratory disease has become a major public health problem in the world. Swine flu is caused by a strain of the influenza type a virus known as $\mathrm{H} 1 \mathrm{~N} 1$, officially referred as novel A/H1N1. ${ }^{1,2}$ Swine influenza was first proposed to be a disease related to human influenza during the $1918 \mathrm{flu}$ pandemic, which was known as Spanish flu (infected about 500 million people and caused approximately 50 million deaths). ${ }^{3,4}$ Since then there have been many outbreaks, and the most recent one in April 2009 was with a new strain of virus. On 11 June 2009, the World Health Organization (WHO) raised its pandemic alert to the highest level. ${ }^{2,5}$ Usually, this disease spreads from pigs or birds to humans; however, the recent form was seen to occur amongst those who haven't any contact with pigs and was found to be spreading from humans to humans, and affecting people of all ages.

Its symptoms are similar to those of influenza in general. It includes fever, cough, sore throat, body aches, headache, chills and fatigue. The flu can make chronic health problems worse. India is ranked 3rd among the most affected countries for cases and deaths of swine flu globally. ${ }^{6,7}$ The highest number of cases were reported in 2009 (27,236), followed by $2010(20,604)$ and 2012 $(5,054$ cases $)$. The highest number of swine flu deaths took place in $2011(1,763)$, followed by 2009 (981) and $2012(405))^{7}$ In 2015 till the end of 11 March there are 
1587 deaths and 27886 positive cases of swine flu have been reported. Maharashtra, Gujarat and Rajasthan are commonly affected states. In Maharashtra 264 deaths and 3500 positive cases have been recorded. Latur is most commonly affected district with 16 deaths and 32 positive cases of swine flu have been noted within short period of 4 months.

Along with specific treatment with Tamiflu, prevention is one of the best strategies to control swine flu cases. Vaccination is most effective method of prevention. The public health experts agreed that one of the most effective ways to control H1N1 pandemic is by vaccinating high risk population. Centre for disease control is now encouraging to everyone to get vaccinated against swine flu. But the awareness about swine flu vaccine is very poor. Health care workers are at a greater risk of contact of such diseases and may also promote their transmission by occupational exposures. As number of cases of swine flu is increasing, medical students, interns and resident doctors are getting panicked as they are exposed to large number of cases. There are very few studies on awareness of swine flu vaccine among medicos. Knowledge, attitude and practice (KAP) of people regarding swine flu are a cornerstone in prevention of virus spread and outbreak. $^{1,7}$

The best medicos can do is to keep themselves informed about the happenings and take necessary steps to prevent the spread of the infection. Adequate amounts of vaccine and antivirals are unlikely to be available early in an epidemic and latter could become ineffective because of resistance. Keeping all this in view this study was designed to assess the awareness, practices and their attitude regarding Swine flu vaccine amongst undergraduate medical students, interns and post graduate medical students of government medical college and tertiary care hospital. The aim of this study was to assess the knowledge, attitude and practice (KAP) regarding swine flu vaccine amongst undergraduate medical students, interns and post graduate medical students of government medical college and tertiary care hospital, Latur, Maharashtra and provide data to improve awareness about Swine flu vaccine.

\section{METHODS}

This study was a cross sectional observational study, carried out during period of April-June 2015 at government medical college and tertiary care hospital, Latur, Maharashtra, India. The study was conducted after approval from the Institutional Ethics Committee. A pre designed and pre tested, multiple choice questionnaires was used to conduct this study. As per guidelines, the minimum sample size required for KAP study is 200 but sample to be more representative of population, a total 250 participants were included in this study. ${ }^{8}$ Written informed consent of the participants was taken and those students who were voluntarily willing to participate had been included in the study. Partially filled forms were excluded. All the selected participants were asked to solve the pre-designed and pre tested questionnaire based on knowledge, attitude and practice regarding swine flu vaccine which took approximately 30 minutes to solve all these questions.

Section A consisted of 16 questions assessing knowledge regarding type, dose, route, time of seroconversion and duration of protection. The responses to these questions were multiple choice types with four options including option don't know to few questions. For each correct answer or yes, score given was $+2,+1$ for maybe, 0 for don't know and -1 for incorrect or no. Those questions having more than one correct answer were assessed separately. Section B consisted of 9 questions regarding attitude towards swine flu vaccination. Response to these questions were yes, no, may be and don't know type. Section $\mathrm{C}$ consisted of 5 questions regarding practices towards the vaccination. Same scoring system was applied for assessing attitude and practices. Source of information among the participants was assessed separately. Data was filled in excel sheet and analysed through statistical package for social science (SPSS) software programme for windows (version 21).

\section{RESULTS}

Out of 250 medical students participated in the study 115 (46\%) were undergraduate, $62(24.8 \%)$ interns and 73 $(29.2 \%)$ were postgraduate students. There were 133 $(53.2 \%)$ males and $117(46.8 \%)$ females participated in this study. $90 \%$ of medical students were aware about the occurrence of epidemic but only $83.2 \%$ knows about the availability of vaccine to prevent swine flu and only 30 $(12 \%)$ students got vaccinated for swine flu.

\section{Results of knowledge regarding swine flu vaccine amongst medical students}

It was seen that $90 \%$ of medical students were aware about the occurrence of epidemic but only $83.2 \%$ were aware about the availability of vaccine to prevent swine flu as shown in Table 1. $136(54.4 \%)$ participants were knowing the type of the vaccine available. 95 (38\%) participants correctly answered that swine flu vaccine can be given by intranasal and intramuscular route. Swine flu vaccine can be given from six months of age was known to $109(43.6 \%)$ students. $71(28.4 \%)$ participants knew about the cost of vaccine. Two-three weeks are required for seroconversion which was correctly marked by 106 (42.4\%). Type of antibody produced by swine flu vaccine was correctly marked by $121(48.4 \%)$. Duration of effectiveness is 1 year which was correctly answered by $107(42.8 \%)$ while $43(17.2 \%)$ participants marked that swine flu vaccine is protective for 10 years. $157(62.8 \%)$ participants marked that all the individuals over 6 months of age specially pregnant women and patients with chronic medical conditions must take swine flu vaccine. $162(64.8 \%)$ participants were aware of contraindication of the vaccine. When asked about interaction only 29 
(11.6\%) participants marked correctly that swine flu vaccine can interact with other drugs. From Table 1 it was observed that awareness among post graduate students regarding swine flu vaccination was more as compared to interns and undergraduate students as percentage of correct answers marked by them were higher than other groups.

Table 1: Questions regarding knowledge and frequency of correct answers marked.

\begin{tabular}{|c|c|c|c|c|c|}
\hline \multirow[t]{2}{*}{ S.No } & \multirow[t]{2}{*}{ Questions } & \multirow{2}{*}{$\begin{array}{l}\text { Correct } \\
\text { Ans. in UG } \\
\text { students } \\
\mathbf{n = 1 1 5 ( \% )}\end{array}$} & \multirow{2}{*}{$\begin{array}{l}\text { Correct } \\
\text { Ans. in } \\
\text { Interns } \\
\mathbf{n = 6 2 ( \% )}\end{array}$} & \multirow{2}{*}{$\begin{array}{l}\text { Correct } \\
\text { Ans. in } \\
\text { PG Students } \\
\mathbf{n = 7 3 ( \% )}\end{array}$} & \multirow{2}{*}{$\begin{array}{l}\text { Total }(\%) \\
\mathbf{n}=\mathbf{2 5 0}(\%)\end{array}$} \\
\hline & & & & & \\
\hline 1 & $\begin{array}{l}\text { Awareness about epidemic of } \\
\text { swine flu? }\end{array}$ & $98(85.2) \%$ & $57(91.9 \%)$ & $70(95.6 \%)$ & $225(90 \%)$ \\
\hline 2 & Availability of the swine flu vaccine? & $87(75.7 \%)$ & $55(88.7 \%)$ & $66(90.41 \%)$ & $208(83.2 \%)$ \\
\hline 3 & Type of vaccine available? & $36(31.3 \%)$ & $38(61.29 \%)$ & $62(84.9 \%)$ & $136(54.4 \%)$ \\
\hline 4 & Route of administration? & $21(18.3 \%)$ & $31(50 \%)$ & $43(58.9 \%)$ & $95(38 \%)$ \\
\hline 5 & Min. age of vaccination? & $35(30.4 \%)$ & $33(53.2 \%)$ & $41(56.2 \%)$ & $109(43.6 \%)$ \\
\hline 6 & Dose in children? & $58(50.4 \%)$ & $38(61.3 \%)$ & $34(46.6 \%)$ & $130(52 \%)$ \\
\hline 7 & Dose in adult? & $53(46.1 \%)$ & $33(53.2 \%)$ & $41(56.2 \%)$ & $127(50.8 \%)$ \\
\hline 8 & Availability of booster dose? & $13(11.3 \%)$ & $13(20.9 \%)$ & $72(23.3 \%)$ & $43(17.2 \%)$ \\
\hline 9 & Cost? & $23(20 \%)$ & $21(33.9 \%)$ & $27(37 \%)$ & $71(28.4 \%)$ \\
\hline 10 & Type of antibody produced? & $56(48.7 \%)$ & $30(48.4 \%)$ & $35(47.9 \%)$ & $121(48.4 \%)$ \\
\hline 11 & Time of seroconversion? & $35(30.4 \%)$ & $28(45.2 \%)$ & $43(58.9 \%)$ & $106(42.4 \%)$ \\
\hline 12 & Duration of effectiveness? & $24(20.9 \%)$ & $33(53.2 \%)$ & $50(68.5 \%)$ & $107(42.8 \%)$ \\
\hline 13 & Indication? & $71(61.7 \%)$ & $37(59.7 \%)$ & $49(67.1 \%)$ & $157(62.8 \%)$ \\
\hline 14 & Contraindication? & $61(53 \%)$ & $44(71 \%)$ & $57(78.1 \%)$ & $162(64.8 \%)$ \\
\hline 15 & Adverse effect? & $31(27 \%)$ & $25(40.3 \%)$ & $27(37 \%)$ & $83(33.2 \%)$ \\
\hline 16 & Drug interaction? & $8(6.95 \%)$ & $10(16.29 \%)$ & $11(15 \%)$ & $29(11.6 \%)$ \\
\hline
\end{tabular}

Table 2: Questions regarding attitude and frequency of favourable answers marked.

\begin{tabular}{|c|c|c|c|c|c|}
\hline $\begin{array}{l}\text { S. } \\
\text { No. }\end{array}$ & Questions & $\begin{array}{l}\text { Favourable } \\
\text { Ans. In } \\
\text { UG Students }\end{array}$ & $\begin{array}{l}\text { Favourable } \\
\text { Ans. In } \\
\text { Interns }\end{array}$ & $\begin{array}{l}\text { Favourable } \\
\text { Ans. In } \\
\text { PG Students }\end{array}$ & $\begin{array}{l}\text { Total } \\
(\%)\end{array}$ \\
\hline & & $\mathrm{n}=115(\%)$ & $\mathrm{n}=62(\%)$ & $\mathrm{n}=73(\%)$ & $\mathrm{n}=250(\%)$ \\
\hline 1 & $\begin{array}{l}\text { Can you get swine flu from swine flu } \\
\text { vaccine? }\end{array}$ & $50(43.5 \%)$ & $18(29 \%)$ & $23(31.5 \%)$ & $91(36.4 \%)$ \\
\hline 2 & $\begin{array}{l}\text { Do you think you can suffer from swine } \\
\text { flu even after taking swine flu vaccine? }\end{array}$ & $28(24.3 \%)$ & $24(38.7 \%)$ & $40(54.8 \%)$ & $92(36.6 \%)$ \\
\hline 3 & $\begin{array}{l}\text { Can you take swine flu vaccine if you } \\
\text { have past H/O of swine flu? }\end{array}$ & $52(45.2 \%)$ & $37(59.7 \%)$ & $43(58.9 \%)$ & $132(52.8 \%)$ \\
\hline 4 & $\begin{array}{l}\text { Can you take swine flu vaccine if you } \\
\text { are suffering from swine flu? }\end{array}$ & $56(48.7 \%)$ & $33(53.2 \%)$ & $37(50.7 \%)$ & $126(50 \%)$ \\
\hline 5 & $\begin{array}{l}\text { Do you think the swine flu vaccine is } \\
\text { safe in pregnancy? }\end{array}$ & $22(19.1 \%)$ & $23(37.1 \%)$ & $32(43.8 \%)$ & $77(30.8 \%)$ \\
\hline 6 & $\begin{array}{l}\text { Can you take any other vaccine along } \\
\text { with the swine flu vaccine? }\end{array}$ & $24(20.9 \%)$ & $20(32.3 \%)$ & $38(52.1 \%)$ & $82(32.8 \%)$ \\
\hline 7. & $\begin{array}{l}\text { Which type of swine flu vaccine would } \\
\text { you like to take? }\end{array}$ & $18(15.7 \%)$ & $25(40.3 \%)$ & $40(54.8 \%)$ & $83(33.2 \%)$ \\
\hline 8. & $\begin{array}{l}\text { Which route of swine flu vaccination } \\
\text { would you prefer? }\end{array}$ & $27(23.5 \%)$ & $39(62.9 \%)$ & $52(71.2 \%)$ & $118(47.2 \%)$ \\
\hline 9. & $\begin{array}{l}\text { Which is your source of information } \\
\text { regarding swine flu vaccine }\end{array}$ & $8(7 \%)$ & $6(9.7 \%)$ & $11(15.1 \%)$ & $25(10 \%)$ \\
\hline
\end{tabular}




\section{Results of attitude towards the swine flu vaccination}

Out of all participants, 91 (36.4\%) participants believed that they could not develop swine flu from the vaccine itself as presented in Table 2. $92(36.6 \%)$ participants thought that they could develop swine flu even after taking swine flu vaccine. $132(52.8 \%)$ participants thoughts that they should take swine flu vaccine even if they had past history of swine flu. 126 (50.4\%) participant marked that they should not take swine flu vaccine if they were suffering from swine flu. When asked about safety of the vaccine during pregnancy only $77(30.8 \%)$ thought that swine flu is safe in pregnancy.
Also only $82(32.8 \%)$ participants marked that the swine flu vaccine can be given with other vaccine but these two vaccine should be given at different sites. 83 (33.2\%) participants would like to take trivalent type of vaccine. Intranasal route was most preferred answer by 118 (47.2\%) medical students followed by intramuscular route by $88(35.2 \%)$. Internet $117(46.8 \%)$ was the most common source of information in medical students followed by television and textbooks. The mean score of answers regarding attitude towards swine flu vaccination was 128.4 which shows favourable attitude towards the vaccination as given in Table 3 and Figure 1.

Table 3: Statistical analysis regarding knowledge, attitude and practice.

\begin{tabular}{|lllll|}
\hline S.No & Parameter & Knowledge & Attitude & Practice \\
\hline $\mathbf{1}$ & Mean & 152.5 & 128.4 & 26 \\
\hline $\mathbf{2}$ & Standard deviation & 148.5 & 75.58 & 114.1 \\
\hline $\mathbf{3}$ & Standard error of mean & 42.87 & 28.57 & 51.01 \\
\hline $\mathbf{4}$ & 25\% percentile & 63.75 & 70 & -77.50 \\
\hline $\mathbf{5}$ & $50 \%$ percentile & 142.5 & 103 & 68 \\
\hline $\mathbf{6}$ & 75\% percentile & 190.80 & 203 & 108.5 \\
\hline
\end{tabular}

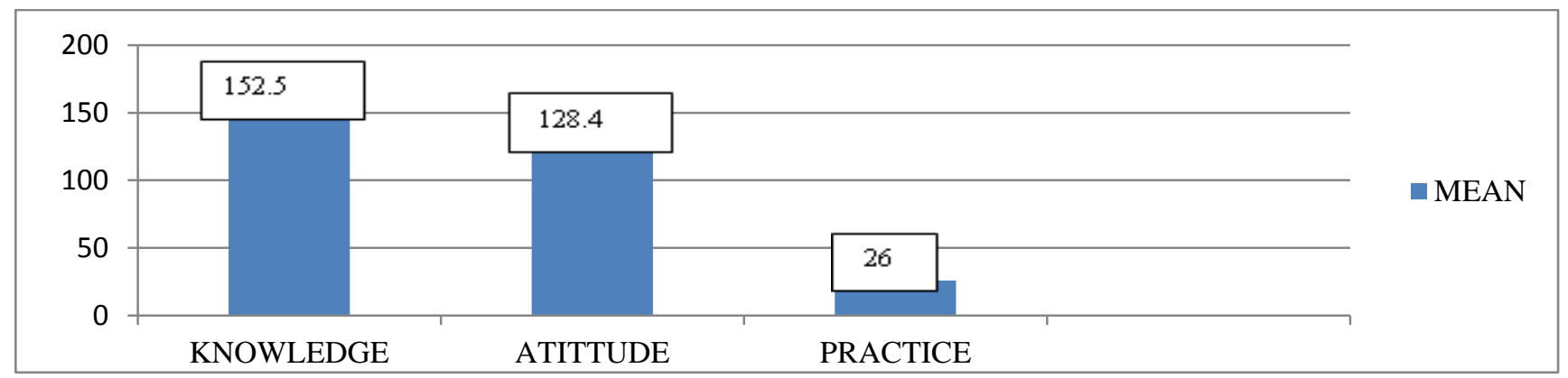

Figure 1: Mean score of knowledge, attitude and practice.

\section{Results of practices amongst the medical students regarding swine flu vaccine}

The immunization rate of the swine flu vaccine in medical students was very low as only 30 (12\%) participants had marked that they had taken the vaccine. Only $73(29.2 \%)$ participants marked that spirit swab was applied before vaccination. $106(42.4 \%)$ participants marked that swine flu vaccine was available in government as well as private hospitals. 29 (51.6\%) participants marked that they can report to treating physician or directly to adverse drug reaction monitoring centre if any adverse drug reaction occurred with swine flu vaccine. Only 54 (21.6\%) participants marked that the vaccine should be taken as soon as possible but preferably in months of September to December as it gives protection to probable epidemic that is more common during months of January to April. It was seen that practises regarding swine flu vaccination were very poor among the medical students as shown in Table 4 and Figure 2.

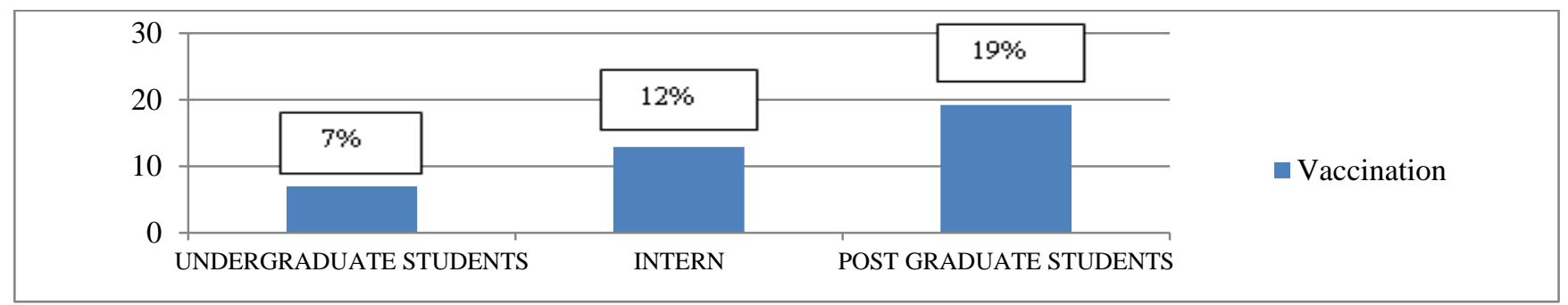

Figure 2: Percentage of vaccination amongst medical students. 
Table 4: Questions regarding practices and frequency of favourable answers.

\begin{tabular}{|llllll|}
\hline S.No & Questions & $\begin{array}{l}\text { Favourable } \\
\text { Ans. In } \\
\text { UG Students } \\
(\mathbf{n = 1 1 5}) \mathbf{( \% )}\end{array}$ & $\begin{array}{l}\text { Favourable } \\
\text { Ans. In } \\
\text { Interns } \\
(\mathbf{n = 6 2})(\%)\end{array}$ & $\begin{array}{l}\text { Favourable } \\
\text { Ans. In } \\
\text { PG Students } \\
(\mathbf{n = 7 3 ) ( \% )}\end{array}$ & $\begin{array}{l}\text { Total } \\
\text { Favourable } \\
\text { Answers } \\
(\mathbf{n = 2 5 0}) \mathbf{( \% )}\end{array}$ \\
\hline $\mathbf{1}$ & $\begin{array}{l}\text { Have you got vaccinated for swine } \\
\text { flu? }\end{array}$ & $8(7 \%)$ & $8(12.9 \%)$ & $14(19.2 \%)$ & $30(12 \%)$ \\
\hline $\mathbf{2}$ & $\begin{array}{l}\text { Whether spirit swab was applied } \\
\text { before administration of swine flu } \\
\text { vaccine? }\end{array}$ & $39(33.9 \%)$ & $20(32.3 \%)$ & $14(19.2 \%)$ & $73(29.2 \%)$ \\
\hline $\mathbf{3}$ & $\begin{array}{l}\text { Where can you report if any adverse } \\
\text { drug reaction occurs due to the swine } \\
\text { flu vaccine? }\end{array}$ & $60(52.2 \%)$ & $32(51.6 \%)$ & $37(50.7 \%)$ & $129(51.6 \%)$ \\
\hline $\mathbf{4}$ & $\begin{array}{l}\text { From where you can get the swine } \\
\text { flu vaccine? }\end{array}$ & $40(34.8 \%)$ & $26(41.9 \%)$ & $40(54.8 \%)$ & $106(42.4 \%)$ \\
\hline $\mathbf{5}$ & $\begin{array}{l}\text { At what period of time you should } \\
\text { take swine flu vaccine? }\end{array}$ & $20(17.4 \%)$ & $14(22.6 \%)$ & $20(27.4 \%)$ & $54(21.6 \%)$ \\
\hline
\end{tabular}

\section{DISCUSSION}

Swine flu is an acute respiratory disease caused by a strain of Influenza type A virus known as H1N1. On $11^{\text {th }}$ June 2009, WHO raised its alert level to phase 6 which shows full global pandemic. Although influenza A/H1N1 has caused pandemic in this century, there are very few studies in this regard on medicos. The distribution of proper information on the status of the H1N1 virus pandemic is important to achieve awareness of the potential risks and to adopt precautionary behaviours. ${ }^{9}$

In our study awareness of medical students about occurrence of swine flu epidemic was $90 \%$ which was less as compared to the study done on interns $98.3 \%$ by Sharma et al. ${ }^{3}$ In this study $83.2 \%$ medical students were knowing about availability of swine flu vaccine which was almost same to the study conducted on dentist in Andhra Pradesh (82.3\%). ${ }^{10}$ But it was more than other studies done by Rathi et.al on urban population in Vadodara $28 \%$ and Singh et al on common educated public in Patiala $60.5 \% .^{11,12}$

In our study participants had considerably good knowledge (mean score 152.5) about swine flu vaccine but there was substantial deficiency of knowledge regarding some aspects of swine flu vaccine. This observed good knowledge in our study may be because of the study was conducted in an academic institute. Another reason may be that the study was conducted when the epidemic of swine flu was at peak. In our study participants had poor knowledge regarding adverse effect $83(33.2 \%)$, drug interaction with vaccine $29(11.6 \%)$, cost $71(28.4 \%)$ and availability of booster dose 43 $(17.2 \%)$ as seen in Table 1 .

Medical students participated in this study had favourable attitude towards swine flu vaccination. Only 35 (14\%) of participants thought that they could develop swine flu from vaccine itself as shown in Table 2. Otherwise most participants marked that they were not panic about development of swine flu from vaccine itself. Attitude towards safety of swine flu vaccine during pregnancy was less favourable as only $77(30.8 \%)$ participants marked that the vaccine is safe in pregnancy. Only $82(32.8 \%)$ participants marked that the swine flu vaccine can be given with other vaccine at different sites as in Table 2.

Vaccination rate among the study participants was less than $20 \%$ as seen in Figure 2. It may because of participants were knowing that the vaccine is effective for one year only. $92(36.8 \%)$ participants thought that they could develop swine flu even after taking the vaccine. Also there was lack of adequate supply of vaccine in the government hospitals.

Surprisingly $129(51.6 \%)$ participants were aware about reporting of any adverse drug reaction due to vaccine to adverse drug reaction monitoring centre. In our study internet was the most common source information regarding swine flu vaccination which was same as that of study done by Mahajan et al on the paediatrician in Chandigarh. ${ }^{13}$ Our study result was in contrast to study done by Datta et al on the paramedical person in which television was main source of information. ${ }^{14}$

As far as KAP study is concerned there is no specific methodology. We have to work on conceptual framework to assess human behaviour. ${ }^{15}$ The triad of knowledge, attitudes and practices in combination help to assess different aspects of life in human societies and all three pillars together help to develop new polices for prevention of diseases. KAP survey, allows exploration of the situation or problem and potentially highlighting aspects that are responsible for spread of disease.

Therefore, we conducted this study to assess increase in knowledge, changes in attitudes toward prevention of swine flu as well as changes in the kinds of practices that were followed regarding prevention of swine flu. 


\section{CONCLUSION}

This study shows high knowledge, favourable attitude but poor practice towards Swine flu vaccination amongst medical students. So there is need to increase awareness for vaccination of swine flu amongst medical students by continuous health education and also need to increase the availability of vaccine in government hospitals.

\section{ACKNOWLEDGEMENTS}

We acknowledge voluntary participation of medical students of Government medical college, Latur, Maharashtra (India). Also thanks to the statistician and Institutional Ethics Committee of the college.

Funding: No funding sources

Conflict of interest: None declared

Ethical approval: The study was approved by the Institutional Ethics Committee

\section{REFERENCES}

1. Shilpa K, Praveen Kumar BA, Kumar SY, Ugargol AR, Naik VA, Mallapur MD. A study on awareness regarding swine flu (influenza A H1N1) pandemic in an urban community of Karnataka. Med J DY Patil Univ. 2014;7(6):732-7.

2. Dandagi GL, Byahatti SM. An insight into the swine-influenza A $(\mathrm{H} 1 \mathrm{~N} 1)$ virus infection in humans. Lung India. 2011;28(1):34-8.

3. Sharma S, Arora VK, Mahashabde P. Knowledge and behaviour regarding swine flu among interns at Index medical college, hospital \& research center, Indore (M.P.). J of Evolution of Med and Dent Sci. 2014;3(10):2590-4.

4. Taubenberger JK, Morens DM. Pandemic influenza - including a risk assessment of H5N1. Rev Sci Tech. 2009;28(1):187-202.

5. Choudhry A, Singh S, Khare S, Rai A, Rawat DS, Aggarwal RK, et al. Emergence of pandemic 2009 influenza A H1N1, India. Indian J Med Res. 2012;135(4):534-7.

6. Kawanpure H, Ugargol AR, Padmanabha BV. A Study to Assess Knowledge, Attitude and Practice Regarding Swine Flu. Int J Health Sci Res. 2014;4(8):6-10.
7. Naik SD, Jain S, Babar SD, Mathurkar MP, Kamble $\mathrm{SV}$, Patil V. A study on awareness regarding swine flu (Influenza A H1N1) pandemic in an urban community of Maharashtra. Sch. J. App. Med. Sci. 2015;3(8):2891-4.

8. Kaliyaperumal K. Guideline for conducting a knowledge, attitude and practice (KAP) study. AECS Illumination. 2004;4(1):7-9.

9. Damor R, Bhabhor H, Kosambiya JK, Gohil A, Rani G, Parmar P. Knowledge, attitude and practices regarding Swine flu among OPD attendees of tertiary care hospital, Surat. IOSR-JDMS. 2015;14(7):60-4.

10. Kaipa S, Epari V, Gupta S. Knowledge and attitude towards swine influenza (2009) among dental practitioners in Nellore district of Andhra Pradesh, India. Ind J Educ Ethics Dent. 2011;1:52-8.

11. Rathi SK, Gandhi H, Bhavsar BS. Modeling for appropriate awareness of H1N1 influenza among urban population of Vadodara, India. Healthline. 2011;2(2):19-23.

12. Singh S, Kaur P, Singh G. Study to assess the awareness, perception and myths regarding swine flu among educated common public in Patiala district. Int J Res Dev Health. 2013;1(2):54-9.

13. Mahajan V, Saini SS. Knowledge, attitude and practices regarding novel H1N1 (swine) Flu among pediatricians of Chandigarh. Indian Pediatr. 2010;47(1):101.

14. Datta SS, Kuppuraman D, Boratne AV, Abraham SB, Singh Z. Knowledge, attitude and practices regarding Swine Flu among para-medical workers in a tertiary care hospital in Pondicherry. J. Commun. Dis. 2011;43(1):1-9.

15. Department of Animal Health, Institute of Tropical Medicine, Antwerp, Belgium. Concepts and challenges in the use of knowledge-attitude-practice surveys: Literature review. 2009. Available at www.snndz.net/./concepts+and+challenges+in+the+ use+of+knowledge. Accessed on 29 Dec 2015.

Cite this article as: Solunke RR, Dharmadhikari SC, Jaju JB, Pawar GR, Gurung A Study to assess knowledge, attitude and practice regarding swine flu vaccine amongst medical students. Int J Basic Clin Pharmacol 2016;5:1978-83. 